\title{
The Intercultural Adaptation Experience of Afghan Students in Malaysia
}

\author{
Abdul Latiff Ahmad ${ }^{1, *}$, Hameedullah Azimi ${ }^{1}$, Sabariah Salleh ${ }^{1}$, Emma Mirza Wati \\ Mohamad $^{1}$ and Shahrul Nazmi Sannusi ${ }^{1}$ \\ ${ }^{1}$ School of Media and Communication Studies, Universiti Kebangsaan Malaysia
}

\begin{abstract}
Studying abroad is an experience which can benefit both students' original and host countries. The Afghan government in their quest to improve the human capital have decided to send their students to pursue their studies abroad. It is hoped that these students not only succeed in their academic endeavor but also to learn from the context of cultural and social experience of others, of the technological and globalising world; and bring the rich experience home to help develop the country. The research uses the U-Curve model of intercultural adjustment (Lysgaard, $1955)$ as the foundation which describes adaptation as a process that moves from a "honeymoon" period into "culture shock" and on to recovery or "adjustment" and "mastery" stages. It looks at the experiences of Afghan students in their adaptation process. Data were obtained from three focus groups discussion done at three different public universities in Malaysia that enrolled the Afghan students. Studies showed that though students went through a bit of culture shock earlier, they are able to adapt in the end which is similar as to the stages discussed in the model.
\end{abstract}

\section{Introduction}

Globalization has significantly contributed towards the movements of students for higher education. Moving into new countries, students are challenged with a new adaptation process, trying to familiarize themselves with new surroundings and new culture.

In this context, globalisation refers more to the sharing and transfer of knowledge between those moving between countries. The growth of knowledge-based economy has changed the level of competition where not only are future employers competitive in seeking the best talent but universities are also becoming more selective in training the future workforce. [1]. On the other hand, internationalisation refers to the awareness, understanding and acceptance on the cultural aspects between those in the higher education globally [2]. Globalisation clearly presents new opportunities, challenges and risks for higher education.

One of the most important subjects in terms of globalisation is migration and cross borders study and this study focuses on the movement of international students, specifically Afghanistan students to Malaysia. In general, globalisation refers to the flow of people,

\footnotetext{
* Corresponding author: alba@ukm.edu.my
} 
technology, culture, values, ideas, knowledge, and economy across borders. There are a large number of definitions of the term "globalisation of higher education"[3].

\section{International Student Experience}

Kim (1988) defined Intercultural communication as "a communication process of using signs and symbols that elicit meaning in another person or persons for whatever intent, or even without conscious intent, on the part of the person producing the symbols or signs" [4]

From the above explanation we understand that intercultural environment are created when two or many different cultures of people are interacting with one another using various symbols as medium. The experience from an this unfamiliar setting can create anxiety, confusion and depression, because for the newcomers, they faced language problems, difficulties in finding accommodation, economic stress, loneliness and these conditions can lead to further problems such as anxiety, despression and various forms of illness.

A research was also conducted on the relationship between students' adjustment factors and their intercultural adaptation process, and they concluded that having travel experience, a high level of education and strong command of languages contributed significantly to the differences in cross-cultural adjustment among participants [5]. The research also found that there is a significant relationship between academic matters, personal, emotional and environmental factors and how an individual is able to adapt in a cross-cultural environment There is also a tendency for international students to stay within their respective cultural members, within a safe enclave [6]. This limits the opportunity for a greater exposure of cross-cultural interaction.

The shortage of higher education places and under-resourced universities in many developing countries has also contributed to many students going overseas to pursue their higher education, and statistics have shown a growing trend of international students from developing countries [7].

\section{Malaysia as an International Education Hub}

Malaysia is making its mark in the international education hub .A report prepared for the UNESCO 2009 World Conference on Higher Education entitled "Trends in global higher education: Tracking an academic revolution", mentioned that more than 2.5 million students are studying outside their home countries [8]. It further predicted that there will be an increase to 7 million international students by 2020 . Malaysia was then placed at the 11 th position in the list of countries with the most numbers of international students, where about $2 \%$ of international students in universities around the world chose Malaysia as their destination for higher education. The Ministry of Higher Education of Malaysia estimates that in the year 2020, they will be able to attract 200,000 international students [9].

\section{The Afghan students}

Afghanistan government sent their first batch of 196 students to Malaysia in 2012. This research will gather the experience of Afghan students' academic life in Malaysia, and focus on the challenges they face in their adaptation process. It looks at the intercultural experience that the students have had and to understand how they dealt with the adjustments.

According to the World Bank report entitled 2013 Higher Education in Afghanistan: An Emerging Mountainscape report, in Afghanistan "only 5 percent of the university academic 
staffs are with Ph.D level of education. Most universities have either no staff with $\mathrm{PhD}$ or just one or two academic staffs with such qualification. Approximately 38 percent of university staffs have Masters, while 57 percent of university staffs have only Bachelor's degrees"[10]. Today, according to the statistic from the Embassy of Afghanistan in Malaysia, there are around 342 students in three public universities in Malaysia. Some of these are students are sponsored while some are not.

The objective of this research is to understand the adaptation process of the Afghans and to explore the challenges they faced while studying in Malaysia. The study was conducted using Lysgaard's (1955) U-Curve model known as intercultural adaptation or cross-cultural adjustment theory which focuses on the four phases of a) Honeymoon, b) Culture shock, c) Adaptation or Adjustment, and d) Mastery phase [11]. This study looks at whether the Afghan students experienced the same stages as those as described in the UCurve model.

\section{Methodology}

This research was conducted in three public universities in Malaysia; Universiti Kebangsaan Malaysia (UKM), Universiti Islam Antarabangsa Malaysia (UIAM), and Universiti Sains Islam Malaysia (USIM). The participants are students who are fully sponsored by the Afghan government that are studying in both the undergraduate and postgraduate level. There are eleven males and three female Afghan students aged from 19 to 33 years old and the programs they are doing are based on the respective Government to Government agreement between Afghanistan and Malaysia. The first group consisted of four male students and one female, the second group consisted of four males while the third group has two males and two females.

\section{Data Analysis}

\subsection{Upon arrival}

The Afghan master students specifically from UKM had nice memories of the warm welcome by the International Relations office of UKM, especially the head of the department. They appreciate the effort and are very thankful to the IR office of UKM and also the Afghanistan embassy for the warm welcome. The undergraduate students were welcomed at the airport by the Afghanistan embassy representatives in Malaysia and also the Afghan students' community of UIAM.

Hamid, (G.1): "I found Malaysia beautiful and peaceful country.... I really forgot all my worries and sadness that I had before coming to Malaysia.... I really appreciate university specially IR office staff of UKM. They help us during coming from the airport to campus and also they provide dinner and morning breakfast for all Afghanistan students."

Salma, (G.3): "First time, when I arrived in Malaysia international airport, we welcomed by representatives of the Afghanistan embassy in Malaysia and also Afghan students who came before us to Malaysia. The first night was really interesting the Afghan student community provided us food and few days were really we don't know where are coming and the beauty of Malaysia keep us so busy."

\subsection{Culture Shock and Homesickness}

Being homesick is common for those who had to leave their home, family and friends when they traveled abroad, away from their comfort zone The Afghan students in UKM (G.1) felt 
depressed as this is the first time he is being away from his family. It is tougher for the married students as they had to be separated from their families and they really missed their children and family.

During the focus group discussion, they cited the problem of living in an unfamiliar environment of the university. They had trouble finding the supermarket and also with the campus transportation system. They were unsure of who to ask and the transportation system was rather complex. As a result they had to walk from one place to another and most of them would just stay in their room due to their frustration with the transportation system.

Shafiq, (G.1): “We walked many kilometers by foot. I remember that we walked from $\mathrm{Za}$ 'Ba College to PPS it takes 30 minutes to arrive there. The weather was too hot. Because university and also the Afghanistan embassy in Malaysia didn't hold any program to help us understand and be familiar with a new environment... I was also with my friends to go outside by foot more than 6 to 7 kilometers to change our money. And buy some necessary things."

One of the Afghan students recalled the three months being completely free with nothing to do. They just ate and slept which made them sick, and they became lazy day by day. The first three months was really depressing for some of them.

Jawed, (G.3): "three months we completely free, there was nothing to do. We just eat and slept which made sick our mind, and we became lazy person. The first three months really put worse or negative effect on our mind, also on our knowledge and learning process becomes slow. One big problem we faced here we cannot sleep at night, in Afghanistan it was normal we go to our bed for sleeping at 10 or 11 pm at night. But here, I can't able to adjust my sleeping time. Here in the Malaysia 4 and 5 am we can't sleep. I also missed my family, the weather, my friends in Afghanistan and Afghanistan people."

The second problem that was mentioned in the group discussion concerns the married students. Prior to coming to Malaysia, they were promised that they could bring their family along, but after arriving in Malaysia, they faced problems in getting visas for their family. It took one year for the visas for their families to be sorted. Khalil (G.1), who was able to get visa for his family after one year, really missed his family in his first month in Malaysia.

Khalil, (G.1): "For Afghanistan people are really difficult to get visas for family during study in Malaysia. I really miss them."

Shafiq, (G.1) came from a very critical war zone (Hilmand Province) in Afghanistan to Malaysia. He also faced the same problems, he was worried about his family in Afghanistan and at the same time he faced some problems in the new environment. All of these make him very stressful.

Shafiq, (G.1): "After that I realized that I came from a far part of the world to Malaysia and feel worried about my family. They lived in a war zone. Also, we had problems of transportation, foods ...."

\subsection{Perception of Malaysians}

Some of them find that the local Malay students are good and friendly in class. The Malay students have a lot of respect for the Afghan students. They seem to be friendly even in the first meeting and tend to smile a lot. In general, female local students are more open minded, and they talk nicely and have good behavior compared to the male locals students. Khalid, (G.2): "We are around 20 Afghan students in the same faculty and same class. I had some local friends also. We always exchange our ideas. Afghan students more they have the same way of thinking and the same idea. I am really happy to talk and have international friends." 
Walid, (G.3): "The first time, when I came to Malaysia, my roommates were all Afghans, after when I started my first semester, university makes some changes and I became roommates of the three locals. We had nice time together, many times they invite me to their house, I traveled with them to their hometown. They are so open mind boys;; there weren't any difference among us. We were so friendly, First days of my life in the Malaysia were limited to my Afghan group friends. Because before coming to Malaysia I don't know anyone of them. .."

\subsection{Similarities of Culture}

Afghan students in Malaysia agree the same religion can be one of the factors, which make it easy the adaptation process for them to fit in the local Malay society. The Afghan students were happy that their government chose a Muslim country as the destination for their higher education. They were able to adapt well to the local environment since the issues of halal food and religion which are the main concerns did not cause them any problems. Malaysia being a multi-cultural and multi-religious country can facilitate foreigners no matter whether they are Muslims or non Muslims.

Farid, (G.1): "it has naturally a few effects, maybe it is negative shock or positive. But for me it was so easy to adapt to the Malaysian culture, maybe one of the reasons because Malaysia a Muslim country, we have access to halal food, Masjid, our study environment is really beautiful with all facilities and also more important Afghanistan government sponsor me a full scholarship."

After staying in Malaysia, the Afghan students now think differently from the past. They mentioned during the focus group discussion about the wrong perception that Afghan in general have about life overseas. They believe that the lack of communication and information on other countries formed their negative perceptions on foreign countries.

Walid, (G.3): "I belong to close society. There in our ancient culture, people think if someone travels, he will lose his religion, and he will be completely changed. And some other negative ideas about overseas. But what I find when I came to Malaysia, it was different from my previous expectation. I was wrong, now I had communicated with different type of people. I learned lots of issues."

The Afghan students stated that once they adapt to the Malaysian environment, they do not face any problem being a foreign student in Malaysia. The only problem that most of them still consider a problem is the spicy Malay food, even though it is not a big problem as Afghani and Arab food are also available at cafes in their campus and also many restaurants nearby.

\section{Discussion and Summary}

The paper aims at presenting the Afghan student academic and cultural life experience in Malaysia. To better understand their life experience in Malaysia, the study presents in the various phases of the students journey in pursuing higher education in Malaysia. The students went through the honeymoon and culture shock stage. Most of them were excited and happy to be pursuing their studies in Malaysia and were touched by the welcome done by the respective universities. They went through the culture shock stage due to some differences between the cultures and when homesickness seems to sink in. Eventually they build more positive perceptions of Malaysians and discovered to focus more on the similarities between the two cultures rather than the differences. These assisted the students throughout their adaptation process in Malaysia. 


\section{References}

1. A.Arokiasamy,. Aust. J. of Bus. and Mngmnt Res.1,9 (2011)

2. R. Yang. Int. Edn. 13,1 (2002)

3. M. Wende, High. Edu. Pol. 14,3 (2002)

4. Y.Y. Kim. Communication and cross-cultural adaptation. (UK, Clevedon, Multilingual Matters, 1988)

5. C.S. Mustaffa and M. Ilias. Int. Comm. St. 22,1 (2013)

6. Y. Chen, H. Chen. Int. Conf. on Bus. Mgmnt and Info. Tech. App.98:233 (2009)

7. R. Yang. Int. Edn. 13,1 (2002)

8. G.A, Philip,L.Reisberg, L.E.. Rumbley, Trends in Global Higher Education: Tracking an Academic Revolution.(2009)

9. A.S. Olutokunbo, I.A. Ismail, T. Suandi. Int. J. Of Learning and Development. 3,6 (2013)

10. Higher Education in Afghanistan: An Emerging Mountainscape. (The World Bank, Washington D.C, 2013)

11. S. Lysgaard. Int. Soc. Sc. Bulletin.7,1 (1955) 